\title{
Performance Study of selected Orange Fleshed Sweet Potato Varieties in North Eastern Bangladesh
}

\author{
Mohammad Abdul Kuddus, Gopal Chandra Datta, Md. Mahbubul Alam \\ Miah, Ashoke Kumar Sarker, Shaikh Md. Abdul Hamid, Atiqur Rahman \\ Sunny
}

Suchana Project, World Fish, Bangladesh and South Asia Office Dhaka-1207, Bangladesh

\begin{abstract}
The study was conducted in Nilgaon and Chamurakandi of Sylhet Sadar Upazila under Sylhet district during the 2018-2019 crop seasons. Three orange fleshed sweet potato varieties (BARI SP-04, BARI SP-11 and BARI SP-12) and a local genotype were used in this study. The ultimate purpose of the experiment was to investigate the yield potentiality, suitability and acceptability of those varieties and genotype. The experiment was performed using loft $x$ loft plot size with 3 replicas following the RCB design. The study showed that BARI SP-12 performed better and local genotype performed least at both places. In Nilgaon BARI SP-12 gave the highest yield (35.27 $\left.t \mathrm{ha}^{-1}\right)$ followed by BARI SP-04 (34.14 tha $\left.{ }^{1}\right), B A R I S P-11$ (32.26 $t \mathrm{ha}^{-1)}$ and the lowest yield was documented in local genotype (24.10 $\left.\mathrm{t} \mathrm{ha} \mathrm{h}^{-1}\right)$. BARI

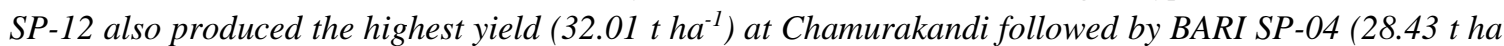
$\left.{ }^{1}\right), B A R I S P-11$ (28.00 $\left.t \mathrm{ha}^{-1}\right)$ and the lowest was documented in local genotype $\left(19.46 \mathrm{t} \mathrm{ha} \mathrm{a}^{-1}\right)$.However, the mean yield of two places appeared the highest in BARI SP-12 (33.64 tha $\left.\mathrm{t}^{-1}\right)$ followed by BARI SP-04 (31.28 $\left.t h a^{-1}\right)$ and BARI SP-11 (30.13 $\left.t h^{-1}\right)$ and the lowest was found in local genotype (21.78 $\left.t \mathrm{ha}^{-1}\right)$. The average foliage yield of two places ranged from 4.82 to $5.38 \mathrm{tha}^{-1}$. And no significant variations were found in foliage yield and foliage coverage (\%) at both places. In the case of organoleptic assessment of storage roots and leaves, BARI SP-04 was the best choice by the respondents due to its appearances, color, taste, texture and fiber content; BARI SP-12 also got merely similar ranked by the respondents. Considering the yield potential and community acceptability, both BARI SP-04 and BARI SP-12 are suitable and potential for homestead food production system in north eastern region of Bangladesh.
\end{abstract}

Keywords- Orange fleshed sweet potato; Potentiality; Foliage coverage; Organoleptic assessment; Homestead production system.

\section{INTRODUCTION}

Bangladesh is located in the South Asia between $20^{\circ} 34^{\prime}$ to $26^{\circ} 38^{\prime} \mathrm{N}$ latitude and $88^{\circ} 01^{\prime}$ to $92^{\circ} 42^{\prime}$ E longitude with an area of $147570 \mathrm{sq} \mathrm{km}$ (Sunny et al., 2020a). The NorthEastern part of Bangladesh especially the Sylhet district is the most traditional in agriculture. In addition, floods caused by heavy rain in June- September adversely affected agriculture (Sunny et al., 2020b). On the other hand scarcity of irrigation water restricted agricultural production especially vegetables that caused price hike due to limited access of vegetables (Islam et al., 2018). The soil productivity is also low comparing with the other part of Bangladesh due to high acidic soil condition. Moreover that the people of the Sylhet regions usually cultivate Aman rice in their crop land and rest times keep fallow. After harvesting Aman rice, some produce Boro rice and some produce vegetables. However, most of the people usually produce vegetables in winter rather than summer due to abundant rainfall and waterlogging .Due to external market situation and climate change in part, vegetables usually grow towards the end of the winter that meets the needs of the household in this area. The poor people mostly intake potato and aroids as vegetables from local market during summer. Hence, the people especially women and children are suffering from hidden hunger due to minimal intake of vitamins and minerals from plant sources. 
According to the Bangladesh Demographic and Health Survey (BDHS 2014) Sylhet division has the highest rates of child stunting $(49.6 \%)$ and under-five mortality (67 per 1,000 live births) in the country. Sylhet also has the lowest female literacy rates, the worst school attendance rates for adolescent girls, the highest gender inequality scores, the worst performance against women's empowerment indicators, and overall the lowest proportion of empowered women in the nation. Suchana is a comprehensive project has been working through nutrition sensitive and nutrition specific intervention in Sylhet region to reduce chronic malnutrition of below 2 children. According to Global Nutrition Report 2018 about 22\% and 36\% children are suffering with stunting globally and nationally respectively.

Sweet potato (Ipomoea batatas L.) is one of the most traditional root crops in many countries like Bangladesh. Its can play an important role in the context of food security in Bangladesh (Hossain and Siddique, 1985). Bangladesh is challenged by hidden food insecurity issues, like micro-nutrient deficiency among small farming households in rural areas, in which more than $43 \%$ of preschool age children are stunted and 56\% are underweight (USAID Horticulture Project, 2013). Sweet potato is one of the most important food crops in terms of caloric value per cultivated area (Scott et. al., 1992). Sweet potato is remarkable because of its high yield, palatability and crude protein content. It's a traditionally regarded as a 'poor man's crop as it is consumed by poor households. It gives satisfactory yield under adverse climatic and soil conditions, as well as under low or non-use of external inputs (Carey et al., 1999 and Kuddus et al., 2018). The sweet potato is rich in carbohydrates and vitamins (Villareal, 1982) and is a potential ally in the fight against vitamin A deficiency. Indeed, recent research results indicate increased availability of beta-carotene (Provitamin A) and crude protein for good nutrition and health (Ukom et al., 2009). Orange-fleshed varieties are rich in betacarotene, while purple-fleshed varieties are high in anthocyanins, two important antioxidants thought to prevent chronic heart diseases and cancer (Teow et al., 2007). Significant amounts of essential minerals are found in the sweet potato, including manganese, copper, iron and potassium (Huang, 1982).Sweet potatoes are now being used in Africa to combat a widespread vitamin A deficiency in 250,000 - 500,000 children. About two-thirds of the children developing xerophthalmia, resulting from lack of vitamin A, die within a year of losing their sight. The strategy of increasing orange flesh sweet potato consumption helps to alleviate vitamin A deficiency
(Anderson et al., 2007). Orange fleshed sweet potato is a promising food from plant sources because of high levels of vitamin- A content ranging from 600 to 7500 IU per 100 $\mathrm{g}$ of fresh storage roots (Mondal et al., 2011) and on an average 1600 IU per $100 \mathrm{~g}$ of fresh leaves (Bhuiyan et al, 2008). Van Jaarsveld et al. (2005) stated that the daily consumption of OFSP have a positive effect on total body vitamin-A assimilation. Tumwegamire et al. (2004) reported that high yielding varieties of OFSP can supply the least expensive, year-round source of dietary vitamin-A to resource poor small farming households.

In addition, several studies showed that orange-fleshed sweet potato is a potential source of vitamin A, minerals (Fe, $\mathrm{Zn}, \mathrm{Mn}$ ), and other micronutrients such as polyphenols and carotenoids (Haskell et al., 2004). Hossain et al., 2016 stated OFSP is viewed as a most promising low-investment nutritional solution for resource poor farming households of developing countries like Bangladesh. Consequently, there is strong potential for reducing micro-nutrient deficiency, particularly vitamin-A deficiency through promoting OFSP cultivation and consumption at household level. Though, OFSP production \& propagation technology is very easy and to some extent drought and acidic tolerance so it could be one of the nutrient sources for poor community at homestead food production system in Sylhet as well as Bangladesh.

Considering above situation the researchers carried out a participatory performance study with four BARI released variety (BARISP-04, BARISP-07, BARISP-08 and BARISP-13) in Suchana working area in 2016-2017 production period and BARISP-04 variety performance found better in terms of production and community acceptability. The present study has been conducted to identify more suitable \& potential variety for Sylhet region in homestead vegetable production system by involving women members. The researchers has selected BARI released another two variety BARI SP-11, BARI SP-12 and a local genotype to compare production as well as community acceptability (Fig.3). Physical appearance of root in raw \& boil condition). So the aim of the study is to find out suitable, potential and acceptable variety for leaf and root production with high micronutrient content by involving women members of the marginal farming households.

\section{MATERIALS AND METHODS}

The study was carried out at two locations of Sylhet region during 2018-19 cropping season. Vines of three BARI developed sweet potato varieties viz. BARI SP-04, BARI 
SP-11 \& BARI SP-12 were collected from Bangladesh Agricultural Research Institute, Joydebpur, Gazipur and local genotype collected from the farmer of that area. Six farmers were selected from Nilgaon and Chamurakandi villages of Sylhet Sadar Upazila of Sylhet district. Vines were planted on 19 November 2018 at both locations having plot size of $10 \mathrm{ft} \times 10 \mathrm{ft}$ with 3 replications following RCB design. Fertilizers were applied in the experimental plots @ 70-25-90 kg/ha of N-P-K as a source of Urea, TSP, and MoP, respectively. Weeding, irrigation, earthing-up, vine lifting and other intercultural operations were done as and when necessary. The sweet potato was harvested on 27 March 2019 and 28 March 2019 at Nilgaon (location 1) and Chamurakandi (location 2), respectively. All the yield and yield contributing characters were recorded and analyzed statistically by using Statistical Tool for Agricultural Research (STAR) software. Mean separation were done following Turkey's Honest Significant Difference (HSD) test at 0.05 level of probability.

Leaf production data was collected after one month of transplanting \& root production data collected at final harvesting time and sensory test was also done after final harvesting. At harvesting stage, participatory variety selection as well as organoleptic evaluation test for leaves and storage roots was done at both locations. Twenty and twenty one participants (scientists, extension staffs and farmers) were gathered to choose better one of the studied sweetpotato variety for storage roots and leaves, respectively at the time of harvesting and the process was done in two separate days. At first, the author briefed the trial objectives and the procedure of evaluation. Then individual voting was done to select the best variety for storage roots and leaves. Each participant tested the variety one after one and placed tick mark range from 1-5. Two kilograms of sweetpotato roots from each variety was boiled. Each boiled variety was placed on a separate plate and clearly identified by number as well as name tag. On the other side's 500 gm of leaves of each variety was fried with equal amount oil and spices by one cook. In case of root, each panelist was given an evaluation form which was used to record the evaluation in reference to the appearance, flesh color, fiber, texture and taste of each variety. And in case of leaves, panelist provided vote for appearance, texture and taste also. The procedures of evaluation were explained to the members of the panels using simple words.

\section{Evaluation of storage roots:}

a. Appearance: The appearance refers to the visual aspect: how the boiled sweetpotatoes from each variety look when presented on plates (Scale: 5=Excellent, 4=Good, 3=Fair, 2=Bad and 1=Very bad)

b. Flesh color: After cross section of boiled sweetpotatoes, how the flesh color look of each variety (Scale: 5= Excellent, 4=Good, 3=Fair, $2=$ Bad and $1=$ Very bad)

c. Taste: The taste is very personal criterion (Scale: 5= Excellent, 4=Good, 3=Fair, 2=bad and 1=very bad)

d. Texture: The texture refers to the dry matter that the sweetpotatoes possess (Scale: 5=Mealy/Floury, 4=Less floury, 3=Fair/Intermediate, 2=Watery/soggy and 1= More watery/soggy)

e. Fiber: The fiber refers to the presence of fiber in boiled sweetpotato flesh with nacked eye (Scale: $5=$ No fiber present, 4=Less fiber present, $3=$ Fair/moderate fiber present, $2=\mathrm{Bad} /$ high fiber present and $1=$ Roots are fibrous)

Evaluation of leaves:

a. Appearance: The appearance refers to the visual aspect: how the fried sweetpotatoes from each variety look when presented on plates (Scale: $5=$ Excellent, 4=Good, 3=Fair, 2=Bad and 1=Very bad)

b. Taste: The taste is very personal criterion (Scale: 5= Excellent, 4=Good, 3=Fair, 2=Bad and 1=Very bad)

c. Texture: The texture refers to the stickiness that the sweet potato leaves possess (Scale: 5=Mealy, 4=Less mealy, 3=Fair/Intermediate, 2=Watery/soggy and 1= More watery/soggy)

\section{RESULTS AND DISCUSSION}

There were no significant difference was found in the case of foliage coverage (\%) at 90 DAP in both locations (Table 1). BAR SP-11 and local genotype exhibited the highest foliage coverage $(100 \%)$ \&BARI SP-12 showed $99.33 \%$ foliage coverage and in both locations but the lowest result $97.67 \%$ recorded in case of BARI SP-04. According to the findings of Burgos et al. (2009) and Kuddus et al.(2018) there was no significant variation of foliage coverage of OFSP genotypes and BARI SP-04. BARI SP-07, BARI SP-08 \& BARI SP-13 variety respectively.

In case of number of storage roots plant- ${ }^{1}$ varied significantly at $(\mathrm{p}<0.05)$ level in both the locations. From location 1 , number of storage root per plant ${ }^{-1}$ ranged from 3.33 to 4.67 where as at location 2 it varied from 3.67 to 
5.67 (Table 1). The highest number of storage roots plant ${ }^{-1}$ was recorded in BARI SP-04 (4.67)in location 1 and BARI SP-11 (5.67) in location 2 and the lowest (3.33 \& 3.67) in local genotype at both location. Farooque and Husain (1973) reported that the number of storage roots plant ${ }^{-1}$ varied from 4.70 to 11.76. Siddique (1985) and Kuddus et al (2018) also found the number of storage roots plant ${ }^{-1}$ which varied from 1.73 to 6.03 and 2.33 to 5.00 respectively.

Table.1: Foliage cover (FC) at 90 DAP and no. of storage roots plant ${ }^{-1}$ at two locations of Sylhet region of Bangladesh during 2018-2019 growing season

\begin{tabular}{|c|c|c|c|c|c|c|}
\hline \multirow{2}{*}{ Variety } & \multicolumn{2}{|c|}{$\mathrm{FC}(\%)$ at $90 \mathrm{DAP}$} & \multirow{2}{*}{ Avg. } & \multicolumn{2}{|c|}{ No. of storage roots plant ${ }^{-1}$} & \multirow{2}{*}{ Avg. } \\
\hline & Location 1 & Location 2 & & Location 1 & Location 2 & \\
\hline BARI SP-04 & $98.33^{\mathrm{a}}$ & $97.67^{\mathrm{a}}$ & 98.00 & $4.67^{\mathrm{a}}$ & $4.33^{\mathrm{bc}}$ & $4.50^{\mathrm{b}}$ \\
\hline BARI SP-11 & $100.00^{\mathrm{a}}$ & $100.00^{\mathrm{a}}$ & 100.00 & $4.33^{\mathrm{a}}$ & $5.67^{\mathrm{a}}$ & $5.00^{\mathrm{a}}$ \\
\hline BARI SP-12 & $99.33^{\mathrm{a}}$ & $99.33^{\mathrm{a}}$ & 99.33 & $4.00^{\mathrm{ab}}$ & $5.00^{\mathrm{ab}}$ & $4.50^{\mathrm{b}}$ \\
\hline Local & $100.00^{\mathrm{a}}$ & $100.00^{\mathrm{a}}$ & 100.00 & $3.33^{\mathrm{b}}$ & $3.67^{\mathrm{c}}$ & $3.50^{\mathrm{c}}$ \\
\hline Mean & 99.42 & 99.25 & 99.33 & 4.08 & 4.67 & 4.38 \\
\hline $\mathrm{CV}(\%)$ & \multicolumn{2}{|c|}{0.543} & & \multicolumn{2}{|c|}{9.71} & \\
\hline $\mathrm{LS}$ & \multicolumn{2}{|c|}{ NS } & & \multicolumn{2}{|c|}{0.05} & \\
\hline
\end{tabular}

Means with the same letters in a column are not significantly different at 5\% level of probability

In case of storage root length a significant difference were found at $(\mathrm{p}<0.05)$ level among the studied varieties in both locations. At location 1, the highest root length $(13.59 \mathrm{~cm})$ was found in BARI SP-04 followed by BARI SP-12 (12.98 $\mathrm{cm})$ \& BARI SP-11 $(11.58 \mathrm{~cm})$ while the lowest was in local genotype $(10.73 \mathrm{~cm})$. But in case of location 2 the highest result shown by BARI SP-12 $(12.65 \mathrm{~cm})$ followed by BARI SP-04 $(11.57 \mathrm{~cm})$ \& BARI SP-11 $(10.73 \mathrm{~cm})$ and the local genotype showed same result trend of location 1 (Table 2). Considering both the locations, average root length ranged from $10.45 \mathrm{~cm}$ to $12.58 \mathrm{~cm}$. The storage root length was a genetic character which differed from variety to variety that agreed with the findings of Siddique (1985) and Kuddus et al (2018).
The study recorded significant variations at $\mathrm{p}<0.05$ level among the varieties on storage root diameter in both locations (Table 2). In location 1, the highest diameter was recorded in BARI SP-12 $(16.17 \mathrm{~cm})$ followed by BARI SP-04 $(13.91 \mathrm{~cm})$, local genotype $(13.73 \mathrm{~cm})$ while the lowest was in BARI SP-11(13.17 cm). But in the case of location 2 the highest diameter $(11.40 \mathrm{~cm})$ was recorded in local genotype followed by BARI SP-04 $(10.63 \mathrm{~cm})$, BARI SP-12 $(9.30 \mathrm{~cm})$ and the lowest was found in BARI SP-11 $(8.43 \mathrm{~cm})$. The mean diameters were varied from $10.80 \mathrm{~cm}$ to $12.74 \mathrm{~cm}$. From the study of Kuddus et al., 2018 found that OFSP root diameter varied variety to variety and location to location.

Table.2: Storage root length $(\mathrm{cm})$ and diameter $(\mathrm{cm})$ of sweetpotato at two locations of Sylhet region of Bangladesh during 2018-2019 growing seasons

\begin{tabular}{l|c|c|c|c|c|c}
\hline \multirow{2}{*}{ Variety } & \multicolumn{2}{|c|}{ Storage root length $(\mathrm{cm}))$} & \multirow{2}{*}{ Avg. } & \multicolumn{2}{c|}{ Storage root diameter (cm) } & \multirow{2}{*}{ Avg. } \\
\cline { 2 - 3 } & Location 1 & Location 2 & & Location 1 & \multicolumn{2}{c}{ Location 2 } \\
\hline BARI-SP -04 & $13.59^{\mathrm{a}}$ & $11.57^{\mathrm{b}}$ & 12.58 & $13.91^{\mathrm{b}}$ & $10.63^{\mathrm{a}}$ & 12.27 \\
BARI-SP -11 & $11.58^{\mathrm{b}}$ & $10.73^{\mathrm{c}}$ & 11.16 & $13.17^{\mathrm{b}}$ & $8.43^{\mathrm{b}}$ & 10.80 \\
BARI-SP -12 & $12.98^{\mathrm{a}}$ & $12.65^{\mathrm{a}}$ & 12.82 & $16.17^{\mathrm{a}}$ & $9.30^{\mathrm{b}}$ & 12.74 \\
Local & $10.73^{\mathrm{c}}$ & $10.17^{\mathrm{c}}$ & 10.45 & $13.73^{\mathrm{b}}$ & $11.40^{\mathrm{a}}$ & 12.57 \\
\hline Mean & 12.22 & 11.28 & 11.75 & 14.24 & 9.94 & 12.09 \\
\hline CV (\%) & \multicolumn{3}{|c|}{3.52} & & & \\
\hline
\end{tabular}

Means with the same letters in a column are not significantly different at $5 \%$ level of probability 
The factor storage roots weight plant $^{-1}$, significant effect was recorded in case all the varieties and both locations at $\mathrm{p}<0.05$ level. The highest storage roots weight plant ${ }^{-1}$ was recorded $(0.94 \mathrm{~kg}$ and $0.85 \mathrm{~kg})$ in BARI SP-12 at location $1 \&$ location 2 respectively while lowest was observed in $(0.64 \mathrm{~kg}$ and $0.52 \mathrm{~kg})$ in local genotype at location $1 \&$ location 2 respectively (Table 3 ). The mean root weight plant $^{-1}$ ranged from $0.58 \mathrm{~kg}$ to $0.90 \mathrm{~kg}$. Considering the factor storage root weight plot $^{-1}$ there is significant variations were found at $p<0.05$ level among the varieties in both locations. In location 1 , the maximum root weight plot $^{-1}(32.78 \mathrm{Kg})$ was noted in BARI SP-12 followed by
BARI SP-04 (31.73 kg) and BARI SP-11 (29.98 kg) while the lowest was in local genotype $(22.40 \mathrm{~kg})$. And in location 2, the highest root weight $\operatorname{plot}^{-1}(29.75 \mathrm{~kg})$ was also found in BAR SP-12 followed by $(26.95 \mathrm{Kg} \& 26.43 \mathrm{Kg}$ ) in BARI SP-11 \& BARI SP-04 respectively but the lowest root weight plot $^{-1}$ was found in local genotype (18.08 $\mathrm{kg}$ ). The average root weight plot $^{-1}$ of two locations ranged from $20.24 \mathrm{~kg}$ to $31.27 \mathrm{~kg}$ (Table 3 ). From the study of Kuddus et al., 2018 was found that storage root weight plant ${ }^{-1}$ and plot $^{-1}$ also varied significantly in different variety and different location.

Table.3: Fresh storage root weight $\left(\mathrm{kg} \mathrm{plant}^{-1}\right)$ and root weight $\left(\mathrm{kg} \mathrm{plot}^{-1}\right)$ of sweetpotatoat two locations of Sylhet region of Bangladesh during 2018-2019 growing seasons

\begin{tabular}{|c|c|c|c|c|c|c|}
\hline \multirow[t]{2}{*}{ Variety } & \multicolumn{2}{|c|}{$\begin{array}{c}\text { Storage root weight } \\
\left(\mathrm{Kg} \mathrm{plant}^{-1}\right)\end{array}$} & \multirow[t]{2}{*}{ Avg. } & \multicolumn{2}{|c|}{$\begin{array}{l}\text { Storage roots weight } \\
\qquad\left(\mathrm{Kg} \mathrm{plot}^{-1}\right)\end{array}$} & \multirow[t]{2}{*}{ Avg. } \\
\hline & Location 1 & Location 2 & & Location 1 & Location 2 & \\
\hline BARI-SP- 04 & $0.91^{\mathrm{a}}$ & $0.76^{\mathrm{b}}$ & 0.84 & $31.73^{\mathrm{a}}$ & $26.43^{\mathrm{b}}$ & 29.08 \\
\hline BARI-SP- 11 & $0.86^{\mathrm{b}}$ & $0.77^{\mathrm{b}}$ & 0.82 & $29.98^{\mathrm{b}}$ & $26.95^{\mathrm{b}}$ & 28.47 \\
\hline BARI-SP-12 & $0.94^{\mathrm{a}}$ & $0.85^{\mathrm{a}}$ & 0.90 & $32.78^{a}$ & $29.75^{\mathrm{a}}$ & 31.27 \\
\hline Local & $0.64^{\mathrm{c}}$ & $0.52^{\mathrm{c}}$ & 0.58 & $22.40^{\mathrm{c}}$ & $18.08^{c}$ & 20.24 \\
\hline Mean & 0.84 & 0.72 & 0.78 & 29.23 & 25.30 & 27.26 \\
\hline $\mathrm{CV}(\%)$ & \multicolumn{2}{|c|}{2.39} & & \multicolumn{2}{|c|}{2.34} & \\
\hline
\end{tabular}

Means with the same letters in a column are not significantly different at $5 \%$ level of probability

The yield contributing factor storage roots per hectare varied significantly at $\mathrm{p}<0.05$ level among the studied varieties in both locations. Due to higher adaptability \& suitability of Sylhet climatic condition, BARI SP-12 produced the highest yield $\left(35.27 \mathrm{t} \mathrm{ha}^{-1}\right)$ followed by BARI SP-04 (34.14 $\left.\mathrm{t} \mathrm{ha}^{1}\right)$ and BARI SP-11 (32.26 t ha' $\left.\mathrm{ha}^{-1}\right)$ while the lowest was produced by local genotype $\left(24.10 \mathrm{t} \mathrm{ha}^{1}\right)$ in location 1. At location 2 BARI SP-12 also produced the highest yield $\left(32.10 \mathrm{t} \mathrm{ha}^{1}\right)$ which was statistically significant with BARI SP-04 (28.43 $\left.\mathrm{tha}^{1}\right)$ and BARI SP-11 (28.00 $\mathrm{t} \mathrm{ha}^{1}$ ) while, the lowest was also produced by local genotype (19.46 $\left.\mathrm{tha}^{1}\right)$. The result trend of location 2 was found comparatively lower than location 1 it may due to soil condition and other intercultural practices done by the farmers. However, the mean yield of two locations appeared the highest in BARI SP-12 (33.64 $\left.\mathrm{t} \mathrm{ha}^{1}\right)$ followed by BARI SP-04 (31.28 $\left.\mathrm{tha}^{1}\right)$ and BARI SP-11 (30.13 $\mathrm{t} \mathrm{ha}^{1}$ ) and the lowest was recorded in local genotype (19.46 $\left.\mathrm{t} \mathrm{ha}^{1}\right)$ (Table 4). The storage root yield of different varieties varied location to location also reported by Hossain et al. (2016) and Kuddus et al. (2018).

Among the studied varieties, there were no significant variations in leave yield $(\mathrm{t} \mathrm{ha})^{1}$ in both locations. At location 1, the leaves yield ranged from $4.88 \mathrm{t} \mathrm{ha}^{1}$ to $5.34 \mathrm{t}$ $\mathrm{ha}^{1}$ and in location 2 it was varied from 4.76 to $5.41 \mathrm{t} \mathrm{ha}^{1}$. The average leave yield of two location ranged from 4.82 to $5.38 \mathrm{t} \mathrm{ha}^{1}$ (Table 4). 
International Journal of Environment, Agriculture and Biotechnology, 5(3)

May-Jun, 2020 / Available: https://ijeab.com/

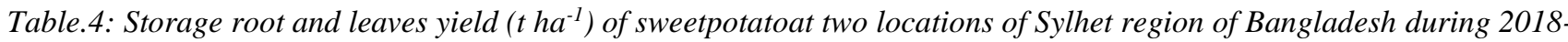
2019 growing seasons

\begin{tabular}{|c|c|c|c|c|c|c|}
\hline \multirow{2}{*}{ Variety } & \multicolumn{2}{|c|}{ Storage root yield $\left(\mathrm{t} \mathrm{ha}^{-1}\right)$} & \multirow{2}{*}{ Avg. } & \multicolumn{2}{|c|}{ Leaves yield $\left(\mathrm{t} \mathrm{ha}^{-1}\right)$} & \multirow{2}{*}{ Avg. } \\
\hline & Location 1 & Location 2 & & Location 1 & Location 2 & \\
\hline BARI-SP-04 & $34.14^{\mathrm{a}}$ & $28.43^{\mathrm{b}}$ & 31.28 & 5.16 & 5.41 & 5.23 \\
\hline BARI-SP-11 & $32.26^{\mathrm{b}}$ & $28.00^{\mathrm{b}}$ & 30.13 & 4.88 & 4.76 & 4.82 \\
\hline BARI-SP-12 & $35.27^{\mathrm{a}}$ & $32.01^{\mathrm{a}}$ & 33.64 & 5.34 & 5.41 & 5.38 \\
\hline Local & $24.10^{\mathrm{c}}$ & $19.46^{\mathrm{c}}$ & 21.78 & 4.98 & 4.88 & 4.93 \\
\hline Mean & 31.44 & 27.22 & 29.33 & 5.09 & 5.12 & 5.10 \\
\hline CV (\%) & & & & & 05 & \\
\hline
\end{tabular}

Means with the same letters in a column are not significantly different at $5 \%$ level of probability

Organoleptic evaluation of sweetpotato leaves and storage roots:

Storage root evaluation: Twenty participants (male and female farmers, scientists and extension staffs) participated in the organoleptic evaluation of storage roots. Considering appearance of the roots, flesh color, taste, presence of fiber and flesh texture, BARI SP-04 ranked first followed by BAR SP-12 while participants' choice was the poorest to BAR SP-11 followed by local genotype (Fig. 1). From the study of (Kuddus et al., 2018) same result trend was found and evaluation panel selected BARI SP-04 as the best one.

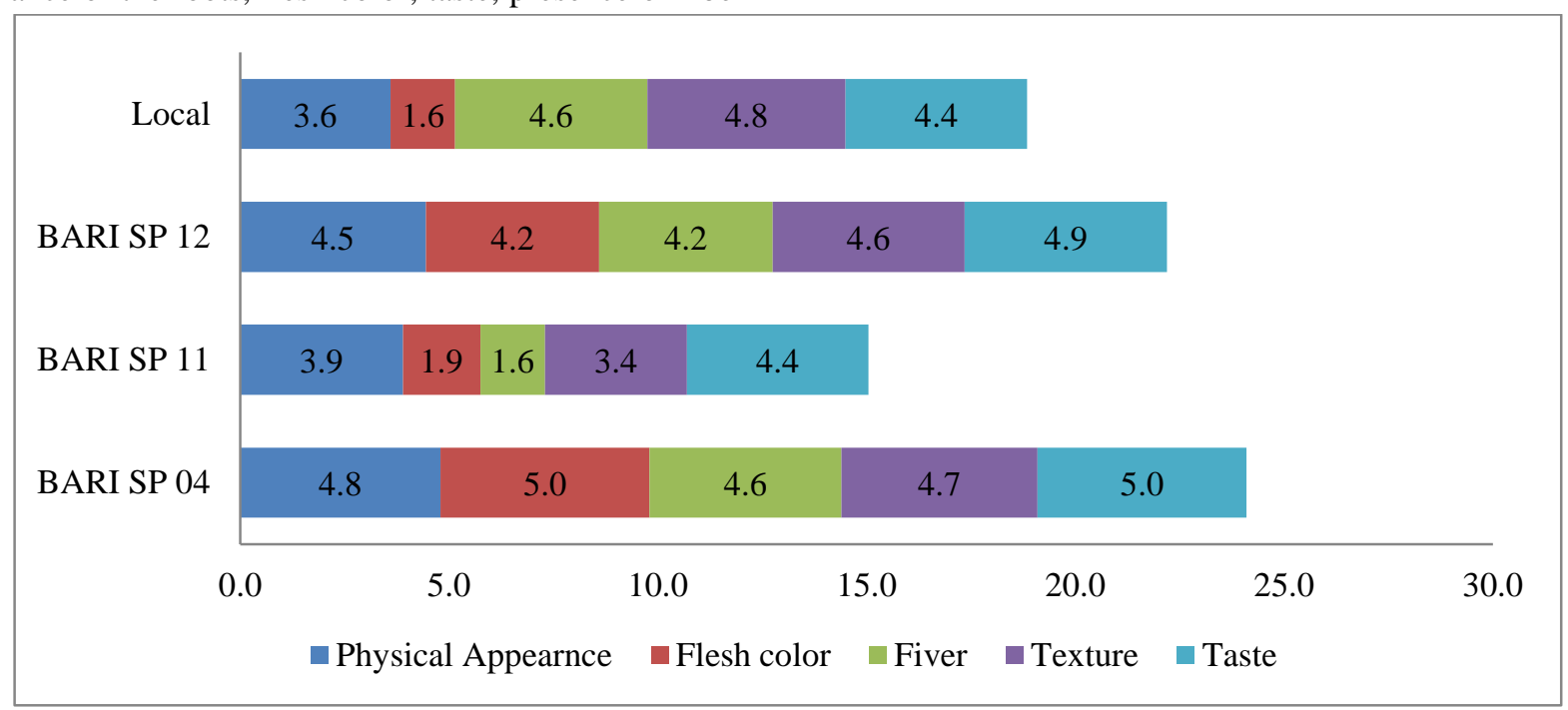

Fig.1. Organoleptic evaluation of storage roots of sweetpotato varieties at Sylhet Region during 2018-2019 growing season. Overall Scale: 5- Excellent, 4-Good, 3-Fair, 2-Bad and I-Very bad

Leaves evaluation: During leaves evaluation, 21 participants (male and female farmers, scientists and extension staffs) participated in the organoleptic evaluation of leaves. The evaluation was done in same way in reference to the appearance, texture and taste of each variety. Considering appearance of the fried leaves, texture and taste, BARI SP-04 ranked first followed by BAR SP12 while participants' choice was the poorest to BAR SP11 followed by local genotype (Fig. 2). 


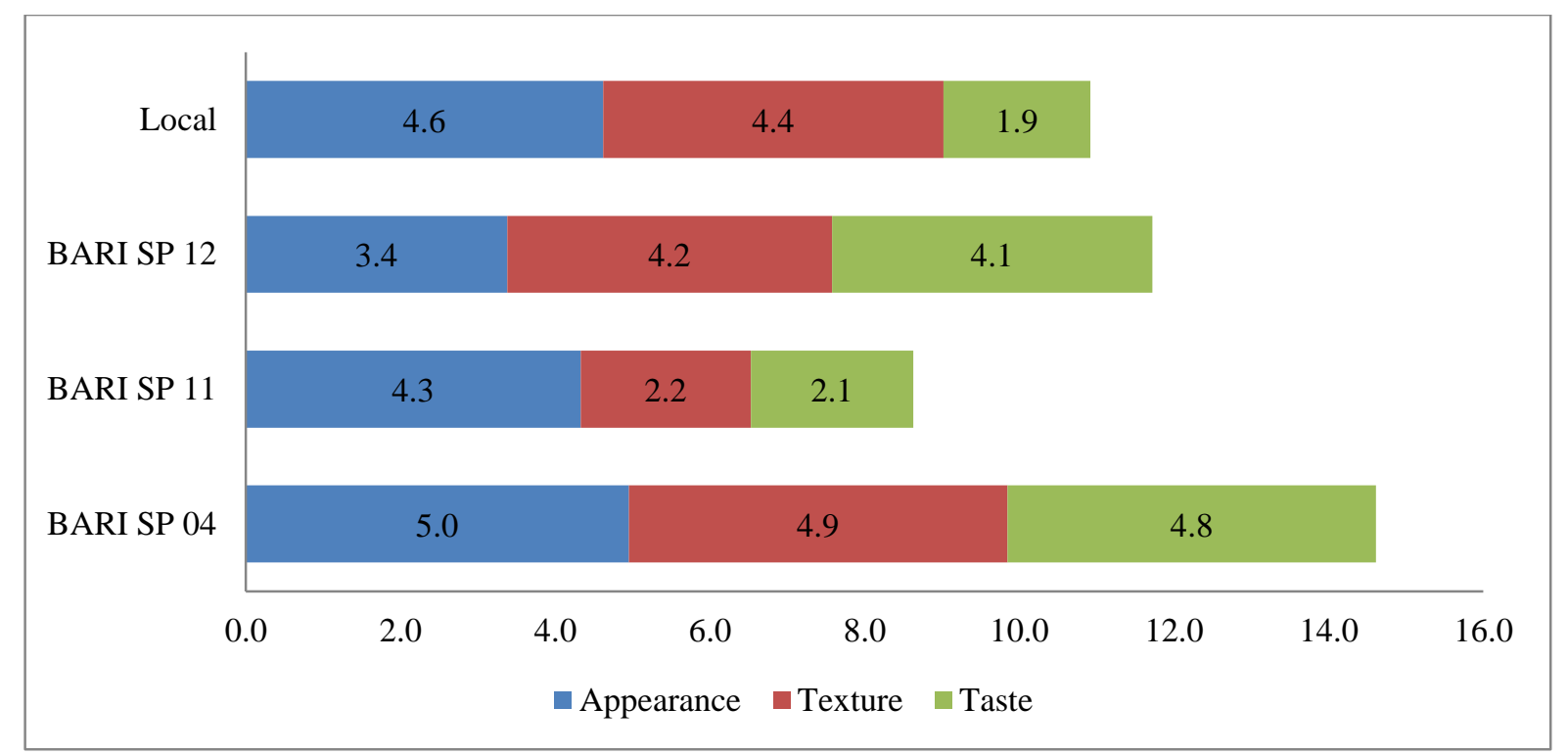

Fig.2: Organoleptic evaluation of leaves of sweetpotato varieties at Sylhet Region during 2018-2019 growing seasons. Overall Scale: 5-Excellent, 4-Good, 3-Fair, 2-Bad and I-Very bad
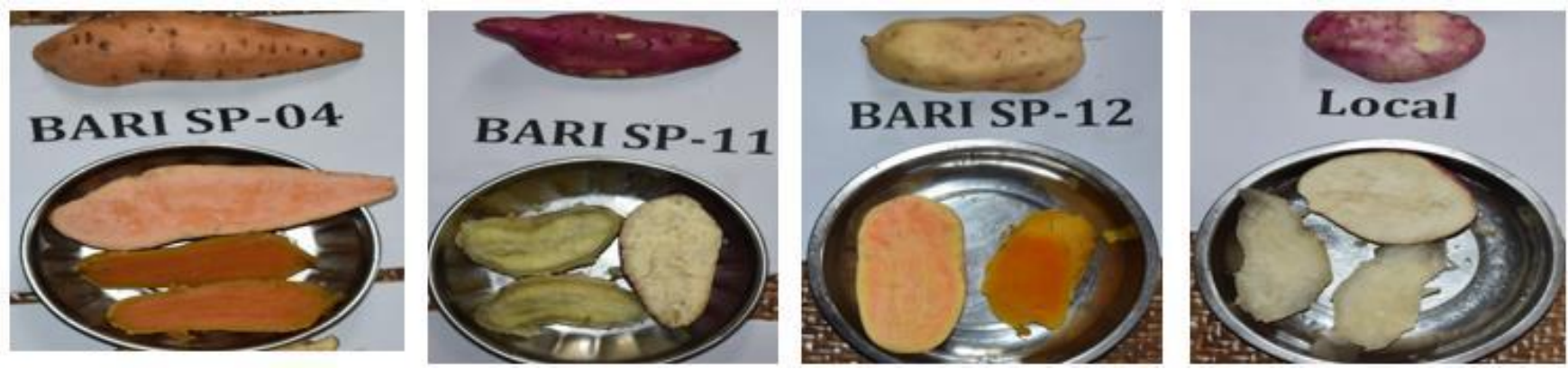

Fig.3: Physical appearance of three varieties and one genotype roots in raw and boil condition

\section{SUMMARY AND CONCLUSION}

According to yield and yield contributing characters, BARI SP-12 was the highest root producer among the studied varieties and genotype followed by BARI SP-04 and BARI SP-11. And the organoleptic evaluation of roots and leaves BARI SP-04 and BARI SP-12 both were found good to excellent and accepted by the farmers. Considering the all aspects, BARI SP-12 and BARI SP-04 both varieties performed better in homestead food production system in north eastern Bangladesh. So, more pragmatic and nutrition sensitive initiative should be taken by the government and nongovernment organizations to promote theses verities up to the marginal community.

\section{ACKNOWLEDGEMENTS}

The authors would like to acknowledge the support provided by the WorldFish Bangladesh under the DFID \&
European Union funded Suchana project for conducting the study. We also like to acknowledge the support of BARI for supplying vines and $\mathrm{SCi}$, HKI \& FIVDB for cooperation for the study. We are very glad to the colleagues who are working in Suchana project for their active cooperation to implement the study and regular follow up data recording and collection. Finally, the authors gratefully acknowledge the support of participating beneficiary households (BHHs) for conducting the study in field level.

\section{REFERENCES}

[1] Anderson P, Kapinga R, Zhang D and Hermann M, 2007. Vitamin a for Africa (VITAA): An entry point for promoting orange-fleshed sweet potato to combat vitamin A- deficiency in sub-Saharan Africa. In: Proceedings of the 13th ISTRC Symposium. Tanzania: Arusha,Tanzania.pp711-720. 
[2] Burgos G, Caprio R, Sanchez C, Sosa P, Porras E, Espinoza $\mathrm{J}$ and Gruneberg W, 2009. Guide for using the RHS color chart for selecting for high $\beta$-Carotene Sweet potato. Poster at ISTRC, Lima, Peru.

[3] Carey EE, Reynoso D, 1999. Procedures for the evaluation of pathogen tested sweet potato clones In: Sweet potato Germplasm Management (Ipomoea batatas) Training manual. International Potato Centre, Lima, Peru pp. 170-186

[4] BDHS (Bangladesh Demographic Health Survey), 2014. National Institute of Population Research and Training Ministry of Health and Family Welfare Dhaka, Bangladesh Mitra and Associates Dhaka, Bangladesh.

[5] Farooque AM and Husain A,1973. Studies on the comparative morphological and the yield of the seven varieties of sweet potato. Bangladesh Horticulture. 1 (2): 37 44.

[6] Global Nutrition Report, 2018.

[7] Haskell MJ, Jamil KM, Hassan F, Peerson JM, Hossain MI, Fuchs GJ and Brown KH, 2004. Daily consumption of Indian spinach (Basellaalba) or sweet potatoes has a positive effect on total-body vitamin A stores in Bangladeshi men. The American Journal of Clinical Nutrition, 80: 705-714

[8] Hossain MM, Shaifullah M, Basak KK and Haque ABMM, 2016. Impact on Production and Consumption of Orange Sweet Potato Varieties in Homestead Vegetable Production System of Poor Farming Households in Bangladesh.Journal of Root Crops,2016, Vol. 42 No. 1, pp. 82-91

[9] Hossain, MM and MA Siddique, 1985. Sweet Potato: Production, Use and Improvement (in Bengali). Mrs, HenaSiddique, Bangladesh Agricultural University Campus, Mymensingh.112 p.

[10] Huang P C, 1982. Nutritive value of sweet potato. In Proceedings of the First International Symposium on Sweet Potato. AVRDC, Taiwan.

[11] Islam MM, Sunny AR, Hossain MM and Friess D, 2018. Drivers of Mangrove Ecosystem Service Change in the Sundarbans of Bangladesh. Singapore Journal of tropical geography, doi:10.1111/sjtg.12241.

[12] Kuddus, MA, Miah MA, Datta GC, SarkerAK, Alam MJ, Hossain M and Hamid SMA, 2018.Participatory evaluation of orange-fleshed sweet potato varieties in Sylhet region. International Journal of Natural and Social Sciences, 5(2): $42-49$

[13] Mondal MRI, Islam MS, Bhuiyan MAJ, Rahman MM, Alam MS and Rahman MSH, 2011. Handbook on Agrotechnology (First part).5th edition. Bangladesh Agricultural Research Institute. Joydebpur, Gazipur-1701. 488 p.

[14] Scott GJ, FergusonPI and HerreraJE, 1992. Product Development for Root and Tuber Crops. Vol. III-Africa. Proceedings of the Workshop on Processing, Marketing, and Utilization of Root and Tuber Crops in Africa, held on October 26 to November 02. 1991 at International Institute for Tropical Agriculture (IITA), Ibadan, Nigeria. CIP, Lima, Peru. 506 p.

[15] SiddiqueMAR, 1985. Studies on the morphology, growth and yield of some sweet potato genotypes. M. Sc.
(Agriculture) Thesis, Dept. of Horticulture, Bangladesh Agricultural University, Mymensingh.

[16] Sunny AR, Alam R, Sadia AK, Miah Y, Hossain S and Mofiz SB, 2020a. Factors Affecting the Biodiversity and Human Wellbeing of an Ecologically Sensitive Wetland of North Eastern Bangladesh. J Coast Zone Manag 23:1. doi: 10.35841/2473-3350.23.1-471

[17] Sunny AR, Reza J, Anas M, Hassan MN, Baten MA, Hasan R, Monwar MM, Solaimoan H and Hossain MM, 2020b. Biodiversity assemblages and conservation necessities of ecologically sensitive natural wetlands of north eastern Bangladesh. Indian Journal of Geo-Marine Sciences, 49 (01): 135-148

[18] Teow CC, Truon V D, McFeeters RF, Thompson RL , Pecota K V and Yench KV, 2007. Antioxidant activities, phenolic and beta-carotene contents of sweet potato genotypes with varying flesh colours. Food Chemistry 103:829-838

[19] Tumwegamire S, Kapinga R, Zhang D, Crissman C and Agili S, 2004. Opportunities for promoting orange-fleshed sweet potato as a mechanism for combat vitamin-A deficiency in Sub-Saharan Africa. J. African Crop Science., 12(3): 241-252

[20] Ukom AN, Ojimelukwe PC and Okpara DA, 2009. Nutrient composition of selected sweet potato [Ipomeabatatas $(L)$ Lam] varieties as influenced by different levels of nitrogen fertilizer application. Pakistan Journal of Nutrition 8 (11): 1791-1795.

[21] USAID (United States Agency for International Development), 2013. Horticulture Project of USAID. CIP/AVRDC, House-74, Road-07, 4th Floor, Block-H, Dhaka-1215.

[22] Van Jaarsveld PJ, Faber M, Tanumihardjo SA, Nestel P, Lombard C.J and Benade AJ, 2005. Beta-carotene-rich orange-fleshed sweet potato improves the vitamin A status of primary school children assessed with modified-relativedose-response test. Am. J. ClinNutr., 81:1080-1087.

[23] Villareal R L, 1982. Sweet potato in the tropics: progress and problems. In Proceedings of the First International Symposium on Sweet Potato. AVRDC, Taiwan. 